\title{
RELATIVE EFFICACY OF SOME PRODUCTS AGAINST MELOIDOGYNE JAVANICA (TREUB) CHITWOOD ON TOMATO UNDER GREENHOUSE CONDITIONS
}

\author{
Abdallah H Almohithef, Fahad A Al-Yahya, Ahmad S Al-Hazmi, \\ Ahmed AM Dawabah ${ }^{1}$ and Hamzeh A Lafi* \\ Plant Protection Department, College of Food and Agriculture Sciences, \\ King Saud University, P.O. Box 2460, Riyadh 11451, Saudi Arabia
}

Keywords: Meloidogyne javanica, Paecilomyces lilacinus, Soft guard ${ }^{\circledR}$, Stanes Bio Nematon ${ }^{\circledR}$, Trichoderma longibranchiatum, Goat and camel manures

\begin{abstract}
A pot experiment was conducted to compare the efficacy of some products i.e., Stanes Bio Nematon ${ }^{\circledR}$, Soft Guard ${ }^{\circledR}$, Paecilomyces lilacinus, Trichoderma longibranchiatum, camel and goat manures against Meloidogyne javanica on tomato under greenhouse conditions. Based on nematode reproduction, indices of galls and egg masses, the six materials were grouped into four classes from the relatively highest efficacy of control (goat manure) to the relatively low efficacy of control (P. lilacinus).
\end{abstract}

Tomato is grown in Saudi Arabia as a commercial vegetable crop. Approximately 12,000 ha planted annually with an estimated yield of more than 200,000 tons (Ministry of environment, water, and agriculture 2018). Tomato plants are very susceptible to fungal, viral, bacterial, and nematode diseases (Lanny 2001). Generally, root-knot nematodes (Meloidogyne spp.) usually cause severe damage in many Saudi vegetable farms (Al-Hazmi et al. 1983). Meloidogyne javanica (Treub) Chitwood causes a serious loss to tomato production in the greenhouses and open fields. Root-knot nematodes are difficult to control, particularly when using a single control method (Barker et al. 1985). Although they showed varying efficacies, different materials and approaches have been used, in Saudi Arabia, to manage root-knot nematodes, including the use of nematicides, resistant cultivars, biological and physical control measures (Al-Hazmi et al. 2017, Abdelrafaa et al. 2018, Al-Hazmi et al. 2019, Dawabah et al. 2019). Collange et al. (2011) presented a review of methods for managing root-knot nematodes, including organic and inorganic fertilizers, sanitation, and biological control. Thus the present study was carried out to compare the relative efficacy of Stanes Bio Nematon ${ }^{\circledR}$, Soft Guard ${ }^{\circledR}$, Paecilomyces lilacinus, Trichoderma longibranchiatum, camel and goat manures as alternatives to methyl bromide for managing $M$. javanica on tomato under greenhouse conditions.

A pot experiment was conducted in a greenhouse $\left(25 \pm 2^{\circ} \mathrm{C}\right)$ with six different materials (Table 1). Seven treatments were arranged in a complete randomized design on a bench. Three weeks old tomato seedlings (cv. Sultana 7) were transplanted singly into each pot. An egg suspension of $M$. javanica was prepared from a pure greenhouse culture on tomato according to Hussey and Barker (1973). The pots were inoculated with 10,000 eggs/pot at seedling transplanting. The egg-parasitic fungus $P$. lilacinus and the antagonistic fungus $T$. longibranchiatum Rifai were isolated from pure cultures of both on potato dextrose agar. For inoculation, each fungus was cultured on wheat grains (Jatala 1986). Two weeks before transplanting the tomato seedlings, each fungal inoculum was mixed at $0.7 \%(10.5 \mathrm{~g} / \mathrm{pot})$ with

*Author for correspondence: <hlafi@ksu.edu.sa>. ${ }^{1}$ Nematode Diseases Research Department, Plant Pathology Research Institute, Agricultural Research Centre, 9 Gamaa Street, Giza 12619, Egypt. 
potting soil in the designated pots. Two bio-products namely, Stanes Bio Nematon ${ }^{\circledR}(1 \times 10 \mathrm{cfu}$ of P. lilacinus per $\mathrm{ml}$ of the product in a liquid formula) and Soft Guard® (chitin oligosaccharides, sea crustaceans) were used in this study. Stanes Bio Nematon ${ }^{\circledR}$ (obtained from T. Stanes \& Company Ltd., Tamil Nadu, India) was applied with irrigation water $(5 \mathrm{ml} / \mathrm{l})$, while Soft Guard $®$ (obtained from Technogreen Company (LEILI), Egypt) was applied using a sprayer on shoot system $(2 \mathrm{ml} / \mathrm{l})$. The two bio-products were applied two weeks before nematode inoculation and every 2 weeks thereafter. Camel and goat manures were also used in this study. The manures were left outside on a board for one week for air-drying, and then ground and sieved. Powders were mixed with the potting soil in the designated pots at $2.0 \%$ (w:w) $(20 \mathrm{~g} / \mathrm{kg}$ soil). Two weeks later, the treated pots were transplanted with tomato seedlings. All seedlings were irrigated and fertilized (Hoagland and Arnon 1950. At sixty days after inoculation with the nematode, fresh plant weights, numbers of root galls, egg masses, and eggs per plant were recorded. The nematode reproduction factor (Oostenenbrink 1966) and indices of gall and egg mass (Sasser et al. 1984) were calculated on a 0-5 scale. Data were statistically analyzed followed by DMRT (SAS 2013).

Table 1. Effects of different materials on root gall and Meloidogyne javanica reproduction in tomato.

\begin{tabular}{|c|c|c|c|c|c|c|c|c|}
\hline Treatment & $\begin{array}{l}\text { No. of } \\
\text { galls/g } \\
\text { of root }\end{array}$ & $\begin{array}{c}\text { No. of egg } \\
\text { masses/g } \\
\text { of root }\end{array}$ & $\begin{array}{l}\text { No. of } \\
\text { eggs/g } \\
\text { of root }\end{array}$ & $\begin{array}{l}\% \text { eggs } \\
\text { reduction }\end{array}$ & $\begin{array}{l}\text { Gall } \\
\text { index }\end{array}$ & $\begin{array}{c}\text { Egg } \\
\text { masses } \\
\text { index }\end{array}$ & $\begin{array}{c}\text { Repro- } \\
\text { duction } \\
\text { factor }\end{array}$ & $\begin{array}{l}\text { Relative } \\
\text { efficacy }\end{array}$ \\
\hline Control & $20.6 \mathrm{a}$ & $18.2 \mathrm{a}$ & $3642 \mathrm{a}$ & - & 5 & 5 & 5.79 & \\
\hline $\begin{array}{l}\text { Paecilomyces } \\
\text { lilacinus }\end{array}$ & $16.2 \mathrm{ab}$ & $10.6 \mathrm{~b}$ & $2126 b$ & 41.6 & 5 & 4.8 & 3.38 & $\mathrm{~L}$ \\
\hline $\begin{array}{l}\text { Trichoderma } \\
\text { longibranchiatum }\end{array}$ & $10.6 \mathrm{c}$ & $6.4 \mathrm{c}$ & $1282 \mathrm{~d}$ & 64.8 & 4.3 & 3.6 & 1.3 & ML \\
\hline Stanes Bio Nematon ${ }^{\circledR}$ & $15.6 \mathrm{~b}$ & $6.6 \mathrm{bc}$ & $1324 \mathrm{c}$ & 63.6 & 4.4 & 3.5 & 0.81 & ML \\
\hline Soft Guard ${ }^{\circledR}$ & $10.8 \mathrm{c}$ & $3.2 \mathrm{~d}$ & $644 \mathrm{e}$ & 82.3 & 4.2 & 3.5 & 0.78 & ML \\
\hline Camel manure & $2.2 \mathrm{~d}$ & $1.0 \mathrm{e}$ & $204 \mathrm{f}$ & 94.4 & 3.4 & 2.9 & 0.33 & MH \\
\hline Goat manure & $1.2 \mathrm{e}$ & $1.0 \mathrm{e}$ & $204 \mathrm{f}$ & 94.4 & 2.9 & 2.8 & 0.33 & $\mathrm{H}$ \\
\hline
\end{tabular}

Means in a column followed by the same letter/s are not significantly different at $\mathrm{P} \leq 0.05$ based on DMRT. $\mathrm{L}=$ Low, $\mathrm{ML}=$ Moderately Low, MH= Moderately High and H= High. Gall index (GI): 1 = 1-2, 2 = 3-10, 3 $=11-30,4=31-100$, and $5=$ more than 100 galls per root system. Egg mass index (EMI): 1 = 1-2, $2=3-10$, $3=11-30,4=31-100$, and $5=$ more than 100 egg masses/root system. Reproduction factor $(\mathrm{Rf})=$ Final nematode population $(\mathrm{Pf}) /$ initial inoculum $(\mathrm{Pi})$.

All the tested materials except $P$. lilacinus reduced $(\mathrm{p} \leq 0.05)$ the number of root galls. All tested materials also reduced the numbers of egg masses and eggs on the roots $(\mathrm{p} \leq 0.05)$, indicating a great reduction (41.6-94.4\%) of nematode reproduction (Table 1). Based on the nematode reproduction and indices of galls and egg masses, the six materials were grouped into four classes, ranging from the relatively lowest to the relatively highest efficacy of control. The goat manure showed the relatively highest control, whereas $P$. lilacinus showed the lowest control (Table 1).

The tested six materials showed differences in control efficacy. Goat and camel manures were the most effective materials which are inexpensive and easy to apply. Results are in agreement with previous reports (Hassan et al. 2010, Abubakar and Adamu 2004) stating that organic materials and wastes suppress reproduction of Meloidogyne spp. The beneficial effects of organic and wastes enhanced crop growth. 
Many abiotic agents induce self-defense mechanisms against plant-parasitic nematodes. This can be an ecological solution for plant protection (Chinassri et al. 2006). Chitin, active ingredient in Soft Guard ${ }^{\circledR}$, stimulates the resistance activity of beneficial microorganisms to control plantparasitic nematodes (Ashoub 2010). Furthermore, chitosan, which is derived from de-acetylated chitin, defends plants against microorganisms (Khalil and Badway 2012) and promotes plant growth (Uthairatanakij et al. 2007. From the results of the present experiment it may be concluded that use of goat or camel manure as an organic additive would be an effective approach as an alternative to methyl bromide for managing root-knot nematodes. The effects of these two materials can be enhanced by combining them with other control measures in an integrated management system. It is very surprising that $P$. lilacinus did not show any appreciable level of control. This could be due to the subculturing of the fungus several times. Further studies, particularly under field conditions, are needed to demonstrate the efficiency and applicability of these two additives.

\section{Acknowledgments}

Authors wish to thank the Agricultural Research Center and Deanship of Scientific Research, King Saud University, Saudi Arabia for supporting this work.

\section{References}

Abdelrafaa OAM, Ahmed EHM, Haroun NE, Dawabah AAM, Al-Yahya FA and Lafi HA 2018. Effect of the introduction time of Trichoderma harzianum into soil on its biocontrol potential against Meloidogyne javanica on tomato plants under greenhouse conditions. Int. J. Curr. Microbiol. App. Sci. 7(5): 18361843.

Abubakar U and Adamu T 2004. Control of Meloidogyne incognita (Kofoid and White) Chitwood of tomato (Lycopersicon lycopersicum Karst) using camel dung. J. Trop. Biosc. 47: 1-3.

Al-Hazmi AS, Dawabah AAM, Al-Nadhari SN and Al-Yahya FA 2017. Comparative efficacy of different approaches to managing Meloidogyne incognita on green bean. Saudi J. Biol. Sci. 24: 149-154.

Al-Hazmi AS, Abul-Hayja ZM and Trabulsi IY 1983 Plant parasitic nematodes in Al-Kharj region of Saudi Arabia. Nematologia Mediterranea 11: 209-212.

Al-Hazmi AS, Al-Yahya FA, Abdelrafaa OAM and Lafi HA 2019. Effects of humic acid, Trichoderma harzianum, and Paecilomyces lilacinus on Meloidogyne javanica. Int. J. Agric., Environ. Biores. 4(1): 61-74.

Ashoub AH 2010. Efficacy and economics of some bio-products in the management of root knot nematodes. Egypt. J. Agronemat. 9: 103-115.

Barker KR, Carter CC and Sasser JN 1985. An advanced treatise on Meloidogyne. Methodology, vol. II. North Carolina State University Graphics, Raleigh, North Carolina, 223 pp.

Chinnasri B, Sipes DP and Schmitt BS 2006. Effects of inducers of systemic acquired resistance on reproduction of Meloidogyne javanica and Rotylenchulus reniformis in pineapple. J. Nematol. 38: 319325 .

Collange B, Navarrete D, Peyer G, Mateille T and Tchamitchian M 2011. Root-knot nematode (Meloidogyne) management in vegetable crop production: the challenge of an agronomic system analysis. Crop Protection 30: 1251-1262.

Dawabah AAM, Al-Yahya FA and Lafi HA 2019. Integrated management of plant-parasitic nematodes on guava and fig trees under tropical field conditions. Egyptian J. Biol. Pest Control. 29: 29. https://doi.org/10.1186/s41938-019-0133-9.

Hassan MA, Chindo PS, Marley PS and Alegbejo MD 2010. Management of root knot nematodes (Meloidogyne spp.) on tomato (Lycopersicon lycopersicum) using organic wastes in Zaria, Nigeria. Plant Protect. Sci. 46: 34-39. 
Hoagland DR and Arnon DI 1950. The water-culture method for growing plants without soil. Bull., Agricultural Experiment Station. College of Agriculture, Univ. California, Berkeley, California.

Hussey RS and Barker KR 1973. A comparison of methods of collecting inocula of Meloidogyne spp., including a new technique. Plant Dis. Res. 57: 1025-1028.

Jatala P 1986. Biological control of plant parasitic nematodes. Annu. Rev. Phytopathol. 24: 453-489.

Khalil MS and Badway MEI 2012. Nematicidal activity of a biopolymer chitosan at different molecular weights against root knot nematode, Meloidogyne incognita. Plant Protect. Sci. 48: 170-178.

Lanny G 2001. Fruit vegetables. In: Crop production in Tropical Africa (Raemaekers R.H., Ed). Brussels, Belgium. 1540.

Ministry of environment, water, agriculture 2018. Statistical Yearbook for 2018, General Authority for Statistics. Riyadh, Kingdom of Saudi Arabia.

Oostenenbrink M 1966. Major characteristics of the relation between nematode and plants. Mededelingen Landbouwhogeschool, Wagenigen, p. 46.

SAS 2013. SAS/STAT 12.3 User's guide. SAS Institute Inc, Cary, NC, USA.

Sasser JN, Carter CC and Hartman KM 1984. Standardization of host suitability studies and reporting of resistance to root-knot nematodes. North Carolina State University Graphics, Raleigh, North Carolina, p. 7.

Uthairatanakij A, Teixeira da Silva JA and Obsuwan K 2007. Chitosan for improving orchid production and quality. Sci. Biotech. 1: 1-5.

(Manuscript received on 20 March, 2019; revised on 11 December, 2020) 